\title{
GROWTH AND REGROWTH OF NEEM AFTER CUTTING IN SALINE - SODIC SOIL TREATED WITH ORGANIC INPUTS ${ }^{1}$
}

\author{
RUMMENIGGE DE MACÊDO RODRIGUES ${ }^{2}$, LOURIVAL FERREIRA CAVALCANTE ${ }^{2}$, ANTÔNIO GUSTAVO DE \\ LUNA SOUTO $^{3}$, HANS RAJ GHEYI ${ }^{4}$, FRANSCISCO DE OLIVEIRA MESQUITA ${ }^{5}$
}

\begin{abstract}
Soil salinity and sodicity are global problems since both promote the physical, chemical and biological degradation of soil, jeopardising the productive capacity of agricultural fields. Inorganic correctives or organic inputs are applied as an attempt to reduce the problem, alongside the use of salt-tolerant plants. This study aimed at evaluating the effects of organic inputs on the growth of neem (Azadirachta indica) strains in saline-sodic soil after cutting. Treatments were arranged in a randomised block design, with four replicates in a $3 \times 5$ factorial. Organic inputs - bovine manure, common bovine biofertilizer (equal parts of water and fresh bovine manure) and chemically enriched biofertilizer (common biofertilizer components combined with plaster, sugarcane molasses and cow's milk) — were applied only once, after soil washing, two days prior to seeding, at the levels of $0,3,6,9$ and $12 \%$ of the substrate volume. Except effects on the stem diameter, the most efficient input was bovine manure, with strong effects on the height increase and biomass yield of neem plants after cutting, especially in treatments at a level greater than $6 \%$. The organic inputs, despite increasing the soil salinity and sodicity in the interval between washing and cutting, stimulated biometric growth and biomass formation in saline-sodic soil.
\end{abstract}

Keywords: Azadirachta indica. Bovine manure. Soil sodicity.

\section{REBROTA E CRESCIMENTO DO NIM APÓS O CORTE EM SOLO SALINO - SÓDICO TRATADO COM INSUMOS ORGÂNICOS}

RESUMO - A salinidade e a sodicidade dos solos são problemas mundiais porque promovem a degradação das propriedades físicas, químicas e biológicas dos solos e comprometem a capacidade produtiva das áreas agrícolas. Uma das tentativas de redução do problema é a aplicação de corretivos inorgânicos ou insumos orgânicos associados com plantas tolerantes aos sais. Pelo exposto, o trabalho objetiva avaliar o efeito de insumos orgânicos na rebrota de cepas de nim (Azadirachta indica) após o corte no crescimento das plantas em solo salino - sódico. Os tratamentos foram arranjados em blocos ao acaso, com quatro repetições em esquema fatorial $3 \times 5$, referentes aos insumos orgânicos - esterco bovino, biofertilizante bovino comum (partes iguais de água e esterco fresco de bovino) e biofertilizante enriquecido quimicamente (componentes do biofertilizante comum associados a gesso, melaço de cana - de - açúcar e leite de vaca), aplicados uma única vez, após a lavagem do solo, dois dias antes da semeadura das sementes, aos níveis de 0,3, 6, 9 e $12 \%$ do volume do substrato. Exceto no diâmetro caulinar, o esterco bovino foi mais eficiente que os biofertilizantes no crescimento em altura e rendimento em biomassa das plantas de nim após o corte, principalmente nos tratamentos em níveis acima de 6 \%. Os insumos orgânicos apesar de elevarem a salinidade e a sodicidade do solo no intervalo do final da lavagem até o corte das plantas, estimularam o crescimento biométrico e a formação de biomassa do nim em solo salino sódico.

Palavras-chave: Azadirachta indica. Esterco bovino. Sodicidade do solo.

\footnotetext{
*Corresponding author

${ }^{1}$ Received for publication in 08/06/2015; accepted in 03/07/2016.

Paper extracted from the Master Science Dissertation of the first author. Project Scientific financed by CNPq and INCTSal.

${ }^{2}$ Agrarian Science Center, Universidade Federal da Paraíba, Areia, PB, Brazil; rummenigge.mr@gmail.com, lofeca@cca.ufpb.br.

${ }^{3}$ Departament of Plant Science, Universidade Federal de Viçosa, Viçosa, MG, Brazil; gusluso@hotmail.com.

${ }^{4}$ Nucleus of Soil and Water Engineering, Universidade Federal do Recôncavo da Bahia, Cruz das Almas, BA, Brazil; hans@pq.cnpq.br.

${ }^{5}$ Departamemt of Environmental and Technological Science, Universidade Federal Rural do Semi-Árido, Mossoró, RN, Brazil; mesquitaagro@yahoo.com.br.
} 


\section{INTRODUCTION}

Soil salinity and sodicity are global problems related to the accumulation of salts and sodium $\left(\mathrm{Na}^{+}\right)$, in solution and in exchange complex, causing degradation of the physical, chemical and biological properties of soil (TEJADA et al., 2006; MAHMOODABADI et al., 2013). These factors cause specific ion toxicity at high concentrations, reduce the absorption of water and essential elements and ultimately lead to reduced crop and food yields (ROY; NEGRÃO; TESTER, 2014).

Recovery of areas with saline-sodic or sodic soils may be achieved with the application of inorganic correctives and organic inputs of animal or vegetable nature, to mitigate the effect of dispersed cations $\left(\mathrm{Na}^{+}\right)$in the soil. In this way, several inputs such as agricultural plaster, sulphuric acid, organic matter and polyacrylamide polymers (PAM) are efficiently used to reduce sodicity and increase plant growth (LEITE et al., 2010; MIRANDA et al., 2011).

Studies using bovine manure and liquid biofertilisers as conditioners have shown their effectiveness in improving the physical and chemical properties of halomorphic soils, providing good conditions for growth and production (REZAPOUR, 2014). Despite these advantages, studies on the prolonged effect of these organic inputs in reducing soil sodicity and plant productive performance are still scarce. According to Silva et al. (2014), bovine manure slowly releases nutrients to the soil, while Marrocos et al. (2012) state that liquid biofertilisers act quickly, with the majority of their nutrients available only during the first fifteen days post application.

Since the beginning of the $21^{\text {st }}$ century, scientific information about the use of native and exotic species (mainly non-food species) has been growing, aiming to exploit their tolerance to salinity as an alternative to reforestation or the physical and chemical recovery of degraded soils contaminated by salts (GURUMURTHY et al., 2007; FREIRE et al., 2010; GHRAB et al., 2013; ISLA; GUILLÉN; ARAGÜÉS, 2014).

In Brazil, according to Holanda et al. (2007), Indian neem (Azadirachta indica A. Juss) stands out among salinity-tested species. A tree of the family Meliaceae, it is known especially in India for its medicinal and insecticide properties, as well as for the resistance and hardness of its wood, which guarantees high longevity of use. Furthermore, its regrowth capacity allows several cuts throughout decades of cultivation (OMKAR, 2012).

Neem is moderately tolerant to salinity (PAZHANIVELAN et al., 2006), meaning that it grows and survives in saline environments with electrical conductivity of the saturation extract between 3 and $6 \mathrm{dS} \mathrm{m}^{-1}$, without significant losses of growth or biomass production (AYERS; WESTCOT, 1999). On the other hand, Diniz et al. (2013) and Mesquita et al. (2015) found that neem behaves as a moderately salt stress sensitive plant.

The present study aimed at evaluating the effects of bovine manure and biofertilisers applied after washing on soil salinity and sodicity and on growth and regrowth after cutting of neem cultivated in pots.

\section{MATERIAL AND METHODS}

The experiment was conducted between January 2012 and January 2013, in a net-protected environment at the Center of Agrarian Sciences, Federal University of Paraíba, Areia, PB, with geographical coordinates $6^{\circ} 67^{\prime} 36^{\prime \prime}$ South and $35^{\circ}$ $41^{\prime} 24^{\prime \prime}$ west at a altitude of $575 \mathrm{~m}$.

The soil used as substrate was sampled at a depth of $0-20 \mathrm{~cm}$ in sector 8 of the Irrigated Perimeter of São Gonçalo, Sousa, PB, and classified as saline-sodic, "chromic luvisoil" (SANTOS et al., 2013). The chemical and physical characteristics of the soil (Table 1) were determined according to Donagema et al. (2011) and Richards (1954).

The experiment consisted of a randomised blocks design with four replicates, using the factorial scheme $3 \times 5$, with three organic inputs (bovine manure, common biofertiliser and chemically enriched biofertilizer) at percentages of the substrate volume of $0 \%$ (without bovine manure or biofertilizer); $3 \%$ (31.2 $\mathrm{t} \mathrm{ha}^{-1}$ of bovine manure and $60 \mathrm{~m}^{3} \mathrm{ha}^{-1}$ of each biofertilizer $) ; 6 \%\left(62.4 \mathrm{tha}^{-1}\right.$ of manure and $120 \mathrm{~m}^{3} \mathrm{ha}^{-1}$ of the biofertilisers); $9 \%$ (93.6 $\mathrm{t} \mathrm{ha}^{-1}$ of manure and $180 \mathrm{~m}^{3} \mathrm{ha}^{-1}$ of the biofertilisers) and $12 \%\left(124.8 \mathrm{t} \mathrm{ha}^{-1}\right.$ of manure and $240 \mathrm{~m}^{3} \mathrm{ha}^{-1}$ of the biofertilisers) applied to the soil. Biofertilizer values $\left(\mathrm{m}^{3} \mathrm{ha}^{-1}\right)$ were calculated relative to the soil volume in the $0-20 \mathrm{~cm}$ layer, while bovine manure values $\left(\mathrm{t} \mathrm{ha}^{-1}\right)$ were calculated using a cattle density of $0.52 \mathrm{~kg} \mathrm{dm}^{-3}$ (Table 2).

Bovine manure derived from dairy cattle of the Areia region, PB and the biofertilisers (common and enriched) were obtained by means of anaerobic fermentation of equal parts $(100 \mathrm{~L}+100 \mathrm{~L})$ of non-saline and non-chlorinated water $\left(\mathrm{ECa}=0.48 \mathrm{dS} \mathrm{m}^{-1}\right)$ and fresh manure of lactating cows (SILVA et al., 2007). As suggested by Leite et al. (2010), $4 \mathrm{~L}$ of molasses, $8 \mathrm{~L}$ of cow's milk and $4 \mathrm{~kg}$ of agricultural plaster $(26 \% \mathrm{CaO}, 17 \% \mathrm{~S}$ and $0.76 \% \mathrm{P}_{2} \mathrm{O}_{5}$ ) were added to chemically enriched biofertilizer. As biofertilisers were applied in liquid form, they were characterised as irrigation water (RICHARDS, 1954), while bovine manure application was based on soil fertility components and on carbon and nitrogen contents (Table 2), according to the methodology proposed by Donagema et al. (2011). 
Table 1. Characterisation of soil chemical and physical properties.

\begin{tabular}{|c|c|c|c|c|c|}
\hline \multirow{2}{*}{$\begin{array}{l}\text { Chemical attributes } \\
\mathrm{pH} \text { in water }(1: 2.5)\end{array}$} & \multicolumn{2}{|r|}{ Saturation extract } & \multicolumn{3}{|c|}{ Physical attributes } \\
\hline & 10.18 & pHps. & 9.34 & Ds $\left(\mathrm{g} \mathrm{cm}^{-3}\right)$ & 1.66 \\
\hline $\mathrm{P}\left(\mathrm{mg} \mathrm{dm} \mathrm{dm}^{-3}\right)$ & 1.83 & $\mathrm{Ca}^{2+}\left(\mathrm{mmol}_{\mathrm{c}} \mathrm{L}^{-1}\right)$ & 3.04 & $\mathrm{Dp}\left(\mathrm{g} \mathrm{cm}^{-3}\right)$ & 2.68 \\
\hline $\mathrm{K}\left(\mathrm{cmol}_{\mathrm{c}} \mathrm{dm}^{-3}\right)$ & 0.09 & $\mathrm{Mg}^{2+}\left(\mathrm{mmol}_{\mathrm{c}} \mathrm{L}^{-1}\right)$ & 1.50 & $\operatorname{Pt}\left(\mathrm{m}^{3} \mathrm{~m}^{-3}\right)$ & 0.47 \\
\hline $\mathrm{Ca}^{2+}\left(\mathrm{cmol}_{\mathrm{c}} \mathrm{dm}^{-3}\right)$ & 2.29 & $\mathrm{~K}^{+}\left(\mathrm{mmol}_{\mathrm{c}} \mathrm{L}^{-1}\right)$ & 0.45 & Sand $\left(\mathrm{g} \mathrm{kg}^{-1}\right)$ & 782 \\
\hline $\mathrm{Mg}^{2+}\left(\mathrm{cmol}_{\mathrm{c}} \mathrm{dm}^{-3}\right)$ & 0.36 & $\mathrm{Na}^{+}\left(\mathrm{mmol}_{\mathrm{c}} \mathrm{L}^{-1}\right)$ & 119.30 & Silt $\left(\mathrm{g} \mathrm{kg}^{-1}\right)$ & 136 \\
\hline $\mathrm{Na}^{+}\left(\mathrm{cmol}_{\mathrm{c}} \mathrm{dm}^{-3}\right)$ & 4.01 & $\mathrm{Cl}^{-}\left(\mathrm{mmol}_{\mathrm{c}} \mathrm{L}^{-1}\right)$ & 86.10 & Clay $\left(\mathrm{g} \mathrm{kg}^{-1}\right)$ & 82 \\
\hline $\mathrm{BS}\left(\mathrm{cmol}_{\mathrm{c}} \mathrm{dm}^{-3}\right)$ & 6.75 & $\mathrm{CO}_{3}{ }^{2-}\left(\mathrm{mmol}_{\mathrm{c}} \mathrm{L}^{-1}\right)$ & 0.64 & $\mathrm{CDW}\left(\mathrm{g} \mathrm{kg}^{-1}\right)$ & 36 \\
\hline $\mathrm{Al}^{3+}\left(\mathrm{cmol}_{\mathrm{c}} \mathrm{dm}^{-3}\right)$ & 0.00 & $\mathrm{HCO}_{3}^{-}\left(\mathrm{mmol}_{\mathrm{c}} \mathrm{L}^{-1}\right)$ & 22.23 & FD $(\%)$ & 55.5 \\
\hline $\mathrm{H}^{+}+\mathrm{Al}^{3+}\left(\mathrm{cmol}_{\mathrm{c}} \mathrm{dm}^{-3}\right)$ & 0.00 & $\mathrm{SO}_{4}^{2-}\left(\mathrm{mmol}_{\mathrm{c}} \mathrm{L}^{-1}\right)$ & $\mathrm{P}$ & DI $(\%)$ & 44.5 \\
\hline $\operatorname{CEC}\left(\mathrm{cmol}_{\mathrm{c}} \mathrm{dm}^{-3}\right)$ & 6.75 & $\operatorname{ECse}\left(\mathrm{dS} \mathrm{m}^{-1}\right)$ & 15.23 & $\mathrm{U}_{\mathrm{cc}}\left(\mathrm{g} \mathrm{kg}^{-1}\right)$ & 15.3 \\
\hline V $(\%)$ & 100.00 & $\operatorname{SAR}\left(\mathrm{mmol} \mathrm{L}^{-1}\right)^{1 / 2}$ & 79.18 & $\mathrm{U}_{\mathrm{pmp}}\left(\mathrm{g} \mathrm{kg}^{-1}\right)$ & 4.4 \\
\hline $\mathrm{OM}\left(\mathrm{g} \mathrm{dm}^{-3}\right)$ & 13.60 & $\operatorname{ESP}(\%)$ & 59.41 & $\mathrm{AW}\left(\mathrm{g} \mathrm{kg}^{-1}\right)$ & 10.9 \\
\hline
\end{tabular}

$\mathrm{BS}=$ sum of bases $\left(\mathrm{Na}^{+}+\mathrm{K}^{+}+\mathrm{Ca}^{2+}+\mathrm{Mg}^{2+}\right) ; \mathrm{CEC}=$ cation exchange capacity $=\mathrm{SB}+\left(\mathrm{H}^{+}+\mathrm{Al}^{3+}\right) ; \mathrm{V}=\mathrm{Base}$ saturation $=100(\mathrm{BS} / \mathrm{CEC}) ; \mathrm{OM}=$ organic matter; $\mathrm{pHps}=\mathrm{pH}$ of the saturated paste; $\mathrm{P}=$ presence; ECse $=$ electrical conductivity of the saturation extract; $\mathrm{SAR}=$ sodium adsorption ratio $=\mathrm{Na}^{+} \mathrm{x}\left[\left(\mathrm{Ca}^{2+}+\mathrm{Mg}^{2+}\right) / 2\right]^{-1 / 2}$; ESP $=$ exchangeable sodium percentage $\left(100 \times \mathrm{Na}^{+} / \mathrm{CEC}\right)$; $\mathrm{Ds}=$ soil density; $\mathrm{Dp}=$ particle density $\mathrm{Pt}=$ total porosity; $\mathrm{CDW}=$ clay dispersed in water; $\mathrm{FD}=$ flocculation degree; $\mathrm{DI}=$ dispersion index; $\mathrm{U}_{\mathrm{cc}}=$ soil water at $0.01 \mathrm{MPa}$; $\mathrm{U}_{\mathrm{pmp}}=$ soil humidity at $1.5 \mathrm{MPa} ; \mathrm{AW}=$ available water.

Table 2. Characterisation of water, common biofertilizer, chemically enriched biofertilizer for irrigation purposes and cattle manure.

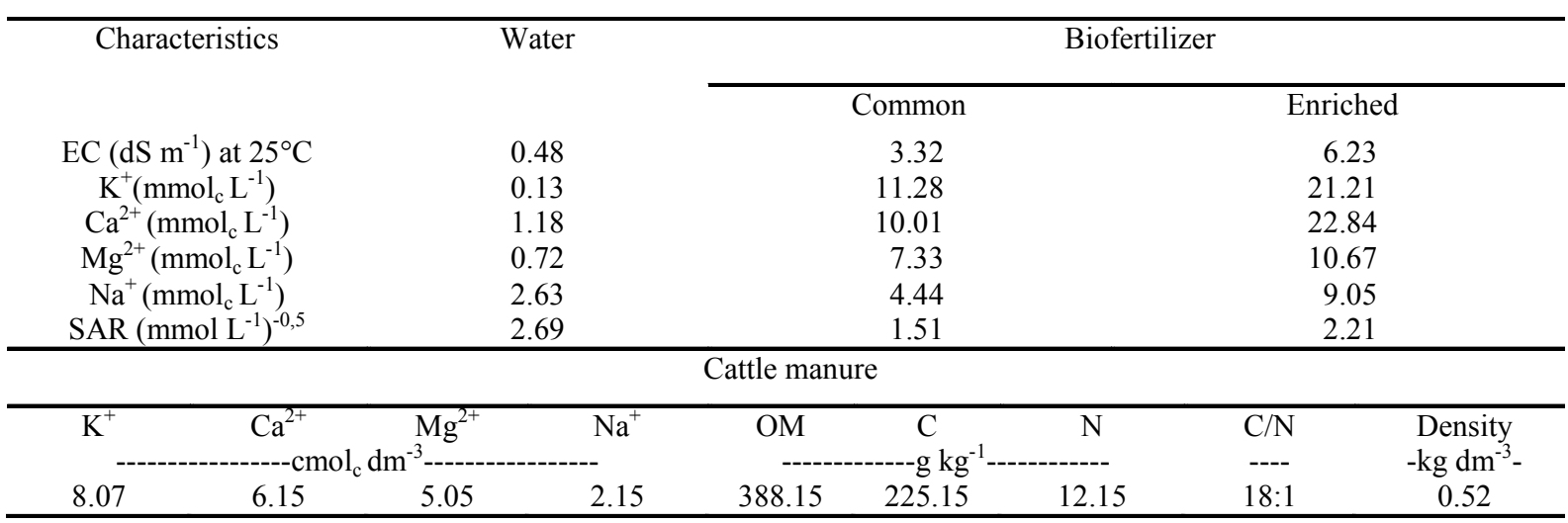

$\mathrm{EC}=$ electrical conductivity; $\mathrm{K}^{+}=$potassium; $\mathrm{Ca}^{2+}$ calcium; $\mathrm{Mg}^{2+}=$ magnesium; $\mathrm{Na}^{+}=$sodium; $\mathrm{SAR}=$ sodium adsorption ratio; $\mathrm{OM}=$ organic matter; $\mathrm{C}=$ carbon; $\mathrm{N}=$ nitrogen; $\mathrm{C} / \mathrm{N}=$ carbon/nitrogen ratio.

Each plot consisted of a pot with $20 \mathrm{dm}^{3}$ capacity, using $13 \mathrm{dm}^{3}$ of soil, with a layer of $4 \mathrm{~cm}$ of gravel zero under $4 \mathrm{~cm}$ of washed sand in the base, in order to avoid losses of soil during the experiment. At the base of the pots, a drain was installed to capture percolated water during soil washing.

Prior to the experiments, the soil was continuously washed for 57 days, with the same water used for soluble salts leaching (RICHARDS, 1954). The surface of each plot was covered with a water layer of $4 \mathrm{~cm}$ and leaching was performed until the drainage water reached an electrical conductivity (ECdw) of $5.0 \mathrm{dS} \mathrm{m}^{-1}$.

Then, from the first $20 \mathrm{~cm}$ of the pot, four samples were collected and combined into one composite sample per pot for the determination of exchangeable cations used to calculate the percentage of exchangeable sodium (ESP) and electrical conductivity of the saturation extract ECse (RICHARDS, 1954). These values are shown in Table 3. Bovine manure was blended with the upper $10 \mathrm{~cm}$ of soil and biofertilizers were applied once at the soil surface, two days before seeding.

Because the soil was saline-sodic, in each experimental unit 24 neem seeds with $92 \%$ viability were planted (BRASIL, 2009) and when the seedlings presented two pairs of leaves, thinning was performed, leaving only the most vigorous plant per pot. Foliar fertilisation was performed with $\mathrm{CaB} 10$ (Ca $8 \%$ and $\mathrm{B} 2 \%$ ), at a dose of $1 \mathrm{~mL} \mathrm{~L}^{-1}$, at 45,60 , 75 and 90 days after seedling emergence, followed by a topdressing with $3 \mathrm{~g}$ of a mixture of urea, simple superphosphate and potassium sulphate at a proportions of 1:1:1.7 (RODRIGUES, 2011). Plant irrigation was performed with the same water previously used for washing, every two days, by the process of lisimetry (weighing), in order to maintain the soil water close to the pot capacity.

At 270 days after seeding, plants were cut at the base, close to the soil surface, and soil samples were collected from each treatment from the 
$0-20 \mathrm{~cm}$ soil layer in order to evaluate both the electrical conductivity of the saturation extract and the percentage of exchangeable sodium
$\left(\mathrm{ESP}=100 \mathrm{Na}^{+} / \mathrm{CEC}\right)$ (Table 3), following Richards (1954).

Table 3. Chemical characterisation of washed soil (AW) immediately after plants cutting (APC), for the evaluation of the growth and regrowth of neem with different types and levels of organic inputs.

\begin{tabular}{|c|c|c|c|c|c|c|c|c|}
\hline \multirow{2}{*}{ Treatment } & \multirow{2}{*}{ Period } & \multirow{2}{*}{ Input level - \% } & \multicolumn{6}{|c|}{ Chemical characterisation } \\
\hline & & & $\mathrm{Ca}^{2+}$ & $\mathrm{Mg}^{2+}$ & $\mathrm{Na}^{+}$ & $\mathrm{K}^{+}$ & ESP & ECse \\
\hline \multirow[b]{2}{*}{ Soil washing } & \multirow[b]{2}{*}{$\mathrm{AW}$} & & \multicolumn{4}{|c|}{---- $\mathrm{cmol}_{\mathrm{c}} \mathrm{dm}^{-3}$----- } & $\%$ & $\mathrm{dS} \mathrm{m}^{-1}$ \\
\hline & & - & 2.12 & 0.34 & 3.21 & 0.04 & 56.22 & 3.00 \\
\hline \multirow{5}{*}{ Cattle manure } & \multirow{5}{*}{ APC } & 0 & 2.05 & 0.94 & 7.01 & 0.20 & 68.72 & 5.16 \\
\hline & & 3 & 2.32 & 0.41 & 13.24 & 0.34 & 81.18 & 5.68 \\
\hline & & 6 & 2.31 & 0.54 & 15.11 & 0.42 & 82.21 & 6.37 \\
\hline & & 9 & 2.91 & 1.13 & 14.94 & 0.77 & 75.65 & 6.91 \\
\hline & & 12 & 2.79 & 3.66 & 14.93 & 0.83 & 67.22 & 8.32 \\
\hline \multirow{5}{*}{$\begin{array}{l}\text { Biofertilizer } \\
\text { common }\end{array}$} & \multirow{5}{*}{ APC } & 0 & 2.05 & 0.94 & 7.01 & 0.20 & 68.72 & 5.16 \\
\hline & & 3 & 1.76 & 0.50 & 21.36 & 0.29 & 89.33 & 4.53 \\
\hline & & 6 & 1.86 & 0.71 & 23.68 & 0.29 & 89.22 & 5.71 \\
\hline & & 9 & 1.83 & 1.02 & 18.22 & 0.27 & 85.38 & 5.98 \\
\hline & & 12 & 2.19 & 1.46 & 13.64 & 0.29 & 77.59 & 4.88 \\
\hline \multirow{5}{*}{$\begin{array}{c}\text { Enriched } \\
\text { biofertilizer }\end{array}$} & \multirow{5}{*}{ APC } & 0 & 2.05 & 0.94 & 7.01 & 0.20 & 68.72 & 5.16 \\
\hline & & 3 & 1.30 & 0.68 & 16.88 & 0.21 & 88.52 & 5.76 \\
\hline & & 6 & 2.37 & 0.87 & 12.24 & 0.27 & 77.71 & 6.93 \\
\hline & & 9 & 2.72 & 1.03 & 10.62 & 0.27 & 75.54 & 7.20 \\
\hline & & 12 & 3.47 & 0.77 & 6.83 & 0.34 & 59.86 & 7.26 \\
\hline
\end{tabular}

Twenty days after cutting, all plants had sprouted and at 90 days after cutting, the effects of the treatments on growth were evaluated by means of plant height, measured from the neck to the insertion of the apical meristem, and the stem diameter measured at the soil surface. The plants were then cut at the base of the aerial part, separated into stem, leaves and twigs and dried in an oven with air circulation at $65{ }^{\circ} \mathrm{C}$ for $72 \mathrm{~h}$, for dry matter quantification of the stem, leaves and aerial parts (stem, leaves and twigs).

Both biomass and biometric growth results were subjected to analysis of variance by means of the " $F$ " test and the relative levels of each input applied to the soil were analysed by regression, using the statistical software SISVAR ${ }^{@}$ (FERREIRA, 2011).

\section{RESULTS AND DISCUSSION}

It can be seen from Table 3 that the soil presented increase in ECse and ESP when different levels and types of organic compounds were applied after washing. Immediately after washing, ECse and ESP were respectively 3.00 and $56.22 \%$, characterising the soil as sodic, and after the application of the inputs, ECse increased to 8.32, 5.98 and $7.26 \mathrm{dS} \mathrm{m}^{-1}$ and ESP to $82.21 ; 89.33$ and $88.52 \%$ respectively in the soils containing bovine manure, common biofertilizer and chemically enriched biofertilizer with plaster, molasses and milk, changing the sodic character of the soil to saline-sodic. The increases in ECse were due to the absence of a leaching (AYERS; WESTCOT, 1999) to wash and remove soluble salts from the soil, while ESP increases are responses to low calcium concentrations in all of the organic inputs (Table 2), meaning that calcium is not available for the replacement of sodium in exchange complexes.

The interaction between the inputs and their respective levels had effects over all analysed variables at 90 days after cutting (Table 4). Considering that all plants cut at the shoot base - at 270 days after emergence regardless of treatment grew and sprouted in saline-sodic soil even with an ECse of $8.32 \mathrm{dS} \mathrm{m}^{-1}$ and an ESP of $89.33 \%$, it appears that neem could grow and sprout in saline-sodic soil. This confirmation is in accordance with Pazhanivelan et al. (2006), who concluded that $85 \%$ of neem plants survived the sodicity effects of a sodic soil with an electrical conductivity of the saturation extract and a percentage of exchangeable sodium of $0.18 \mathrm{dS} \mathrm{m}^{-1}$ and $25.6 \%$, respectively, lower values than those found in Table 3 for these variables.

Bovine manure provided a greater height increase in plants after cutting, compared with common and enriched biofertilizer (Figure 1). Plants treated with manure displayed increased linear height growth after cutting (regrowth) from 38.5 to $114.2 \mathrm{~cm}$, while those treated with enriched biofertilizer increased from 40.45 to $76.45 \mathrm{~cm}$, comparing plants in soils with and without the maximum levels of the inputs. Plants treated with common biofertilizer showed increased growth from 40.47 to $57.93 \mathrm{~cm}$ comparing plants on soils without organic inputs and with the maximum estimated 
level of $7.3 \%$ of the referred liquid input. By linking the highest and lowest value of each input, increases of 196.4, 89.0 and $43.3 \%$ were observed, provided by bovine manure, chemically enriched biofertilizer and common biofertilizer, respectively.

Table 4. Summary analysis of variance for height growth (HG), stem diameter (SD), mass of the dry matter of the stem (MDMS), leaves (MDML) and shoots (MDMST), 90 days after cutting, in neem plants grown in saline-sodic soil treated with different types and levels of organic input.

\begin{tabular}{|c|c|c|c|c|c|c|}
\hline \multirow[t]{2}{*}{ SV } & DF & $\mathrm{HG}$ & SD & MDMS & MDML & MDMST \\
\hline & & \multicolumn{5}{|c|}{ Mean Square } \\
\hline Blocks & 3 & $135797.77^{\mathrm{ns}}$ & $3663.86^{\mathrm{ns}}$ & $9418.86^{\mathrm{ns}}$ & $1379.51^{\mathrm{ns}}$ & $60072.31^{\mathrm{ns}}$ \\
\hline Inputs (I) & 2 & $32732166.66^{* *}$ & $17065.86^{\mathrm{ns}}$ & $3493186.01 * *$ & $1152823.20^{* *}$ & $8208002.40 * *$ \\
\hline Levels (L) & 4 & $30284166.66 * *$ & $43562.23^{* *}$ & $1847039.93^{* *}$ & $680140.93 * *$ & $4363574.26^{* *}$ \\
\hline $\mathrm{I} \times \mathrm{L}$ & 8 & $10504666.66^{* *}$ & $38988.03 * *$ & $955539.43 * *$ & $309439.53 * *$ & $2353916.06^{* * *}$ \\
\hline Residue & 42 & 279547.77 & 7001.81 & 17980.98 & 5750.84 & 35695.07 \\
\hline Total & 59 & --- & --- & --- & --- & --- \\
\hline CV (\%) & & 8.44 & 9.27 & 9.48 & 10.91 & 8.94 \\
\hline
\end{tabular}

$\mathrm{I}_{1}=$ bovine manure; $\mathrm{I}_{2}=$ common biofertilizer; $\mathrm{I}_{3}=$ enriched biofertilizer. ${ }^{\mathrm{ns}}=$ not significant; $*$ and $* *=$ significant at 0.05 and 0.01 of probability by $F$ test.

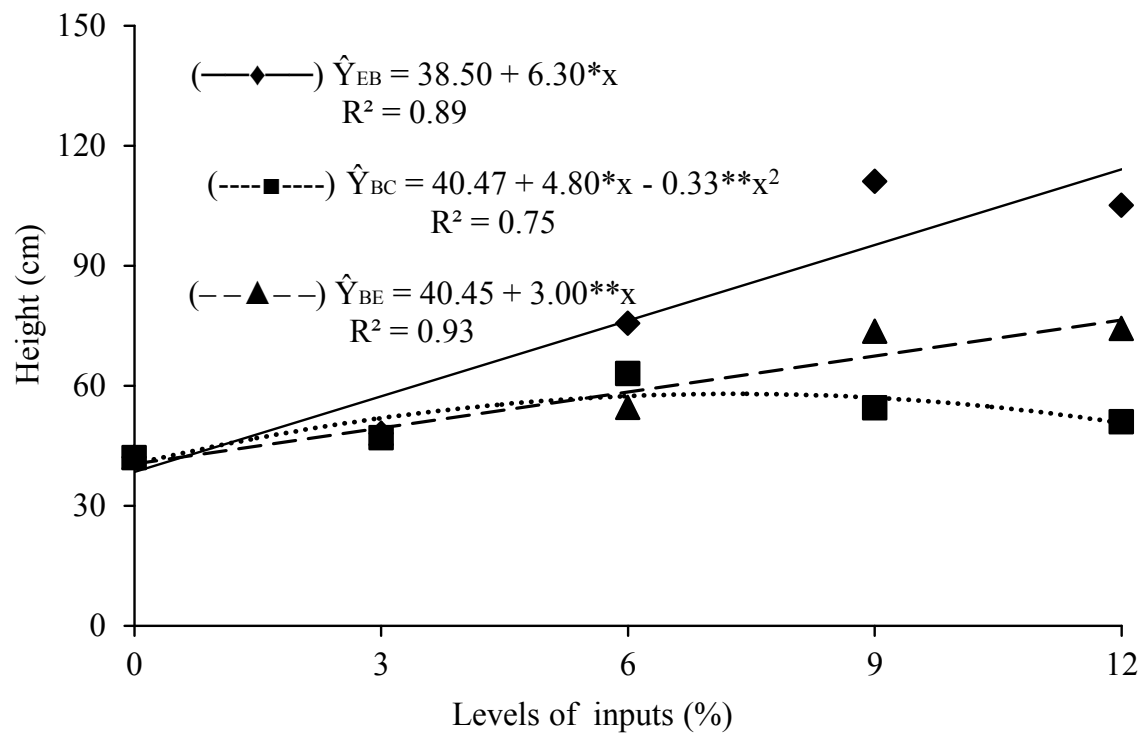

Figure 1. Neem height after cutting (regrowth), under the influence of different levels of bovine manure $\left(\hat{\mathrm{Y}}_{\mathrm{EB}}\right)$, common biofertilizer $\left(\hat{\mathrm{Y}}_{\mathrm{BC}}\right)$ and chemically enriched biofertilizer $\left(\hat{\mathrm{Y}}_{\mathrm{BE}}\right)$, in saline-sodic soil.

The highest values obtained for bovine manure treated plants (Figure 1) are responses to higher nutrient concentrations compared with biofertilizers (Table 2) and to the action of manure as a soil physical conditioner. Manure provides increased porous space to the radicular system (DUNJANA et al., 2012) and improved soil fertility (BENBOUALI et al., 2013; SILVA et al., 2014), resulting in greater vegetative growth compared with soil treated with biofertilizers diluted in water. The superiority of the chemically enriched biofertilizer over the common fertiliser is due to its additional components such as plaster (a source of calcium and sulphur) (LEITE et al., 2010), cow's milk (rich in proteins, vitamins, calcium, phosphorus, potassium, magnesium and zinc) (NASCIMENTO et al., 2010) and molasses (a source of sugars, phosphorus, potassium, calcium, magnesium, sulphur and iron) (COPERSUCAR, 1988).
Regarding stem diameter, the common biofertilizer promoted greater plant growth comparing to bovine manure and chemically enriched biofertilizer (Figure 2). Common biofertilizer increased the diameter from 8.35 to $10.11 \mathrm{~mm}$ comparing plants subjected to treatments without and with the maximum estimated level of $5.4 \%$ of the applied input. The average values for plants treated with manure and enriched biofertilizer at 90 days after cutting, essentially did not vary with the levels of inputs or from each other, with average values of 9.31 and $9.03 \mathrm{~mm}$, respectively.

When comparing the largest stem diameter of $10.11 \mathrm{~mm}$ with the other values in Figure 2, it can be observed that the stem diameter of the plants treated with common biofertilizer exceeded those treated with bovine manure and enriched biofertilizer by 8.6 and $11.9 \%$, respectively. 


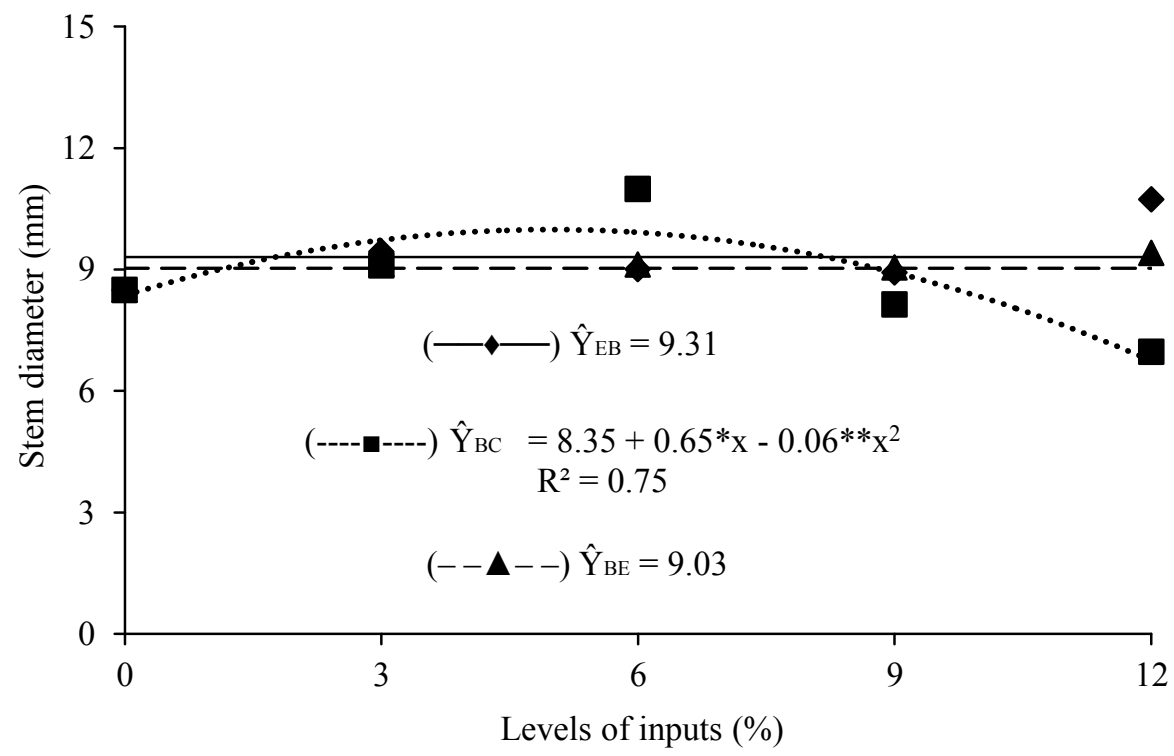

Figure 2. Diameter of neem plants after cutting (regrowth), as a function of bovine manure $\left(\hat{\mathrm{Y}}_{\mathrm{EB}}\right)$, common biofertilizer $\left(\hat{\mathrm{Y}}_{\mathrm{BC}}\right)$ and chemically enriched biofertilizer $\left(\hat{\mathrm{Y}}_{\mathrm{BE}}\right)$ levels in saline-sodic soil.

The action of humic substances derived from the decomposition of organic matter, as biofertilizers and bovine manure, to attenuate negative effects of salinity and sodicity of soils on the biometric growth of plants is as a result of a joint actions comprising physical improvement allowing better root growth, chemical improvement of soil fertility and biological improvement of the diversity of edaphic fauna, as well as stimulation of soil enzymatic activities (TEJADA et al., 2006; MIRANDA et al., 2011; MARROCOS et al., 2012; MAHMOODABADI, et al., 2013).

The dry matter mass of the stem (DMMS) after plants were cut, as observed for height increase, responded more strongly to bovine manure compared with biofertilisers applied to the soil, with a greater difference between bovine manure and the other organic inputs (Figure 3). Increases in dry matter production were from 8.4 to $30.1 \mathrm{~g}$ comparing plants without and with the maximum level of manure and from 8.9 to 13.2 and 8.1 to $14.3 \mathrm{~g}$, respectively comparing plants without and with the maximum estimated level of $7.3 \%$ of each kind of biofertilizer. Such increases confirm the mitigating action of organic inputs on both salinity and sodicity of soil. The effect was greater for proportions of bovine manure higher than $3 \%$ (Figure 3 ) and had a greater effect on the moderate tolerance of neem to sodicity (PAZHANIVELAN et al., 2006).

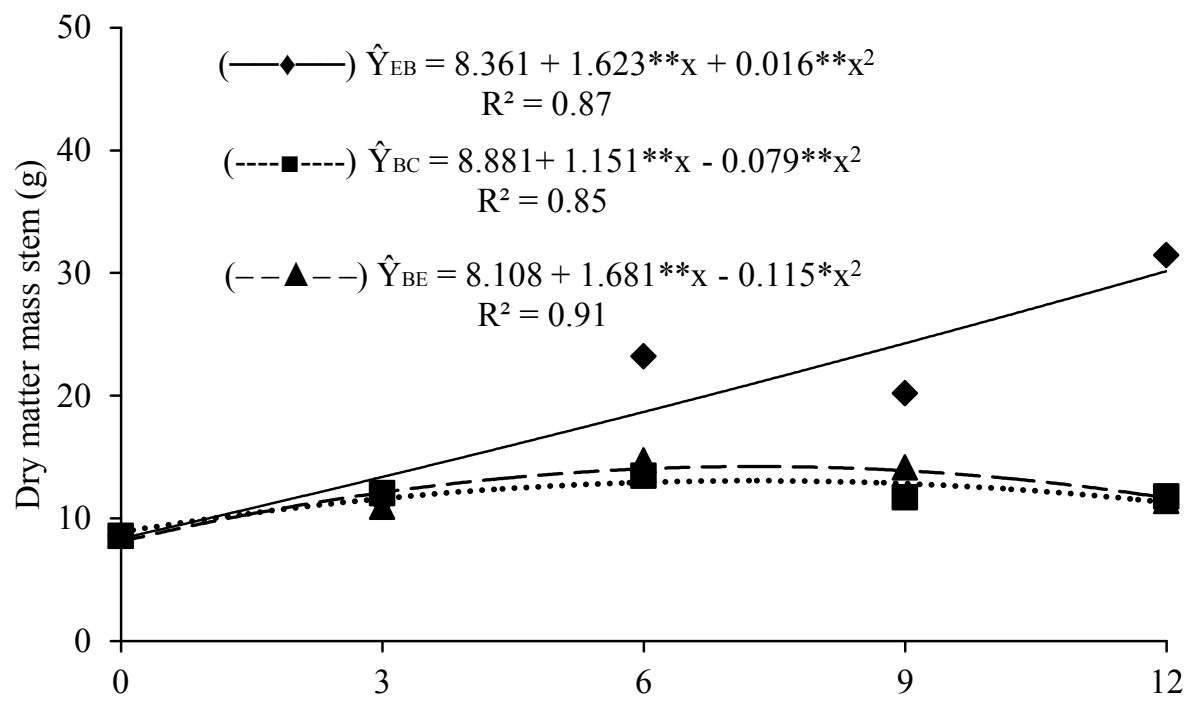

Levels of inputs (\%)

Figure 3. Dry matter mass of neem stem after cutting (regrowth), at different levels of bovine manure ( $\left.\hat{\mathrm{Y}}_{\mathrm{EB}}\right)$, common biofertilizer $\left(\hat{\mathrm{Y}}_{\mathrm{BC}}\right)$ and chemically enriched biofertilizer $\left(\hat{\mathrm{Y}}_{\mathrm{BE}}\right)$ treatment in saline-sodic soil. 
The dry matter of neem leaves after cutting (regrowth) increased with the levels of organic inputs, but always proportionally greater in treatments with bovine manure, followed by common biofertilizer and enriched biofertilizer (Figure 4). The values increased from 3.78 to
$16.70 \mathrm{~g}$, from 4.52 to $7.33 \mathrm{~g}$ and from 3.61 to $6.86 \mathrm{~g}$, respectively between treatments without and with $12 \%$ bovine manure, common biofertilizer and enriched biofertilizer containing plaster, milk and sugarcane molasses (Figure 4).

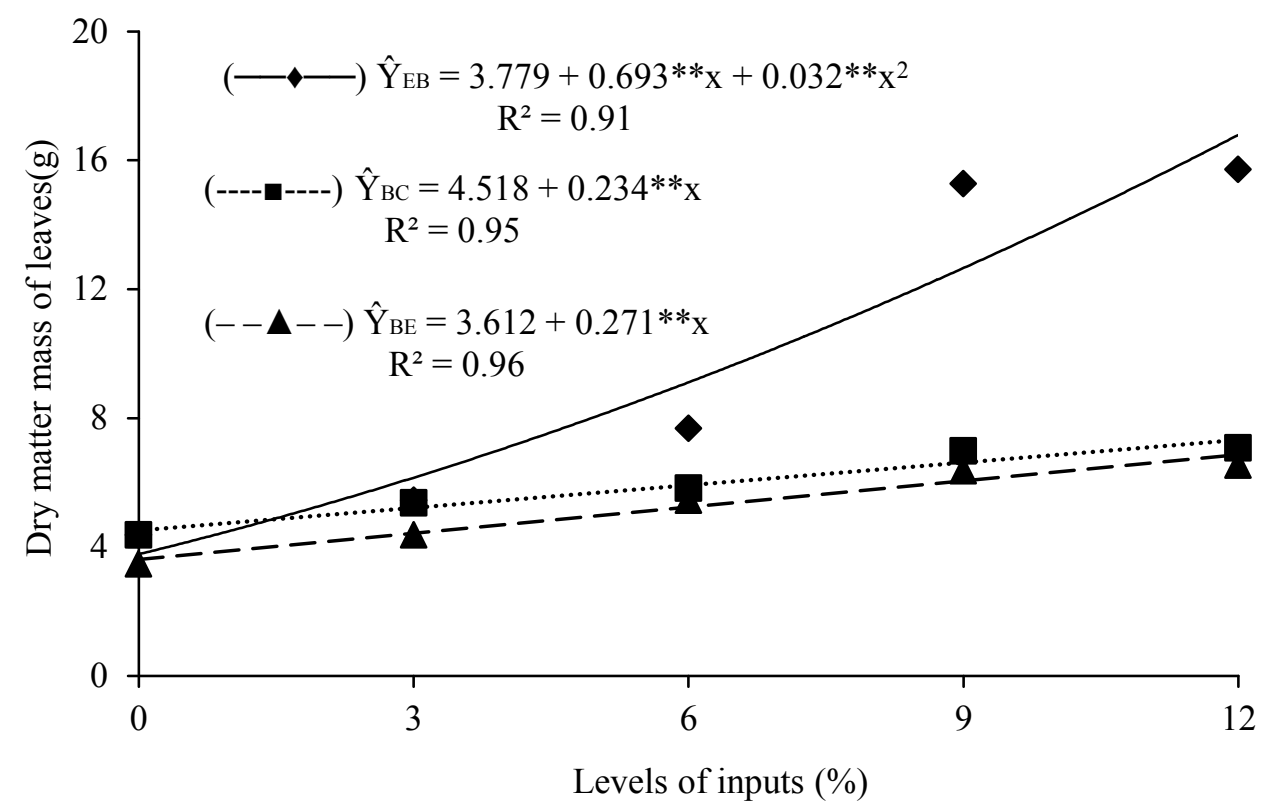

Figure 4. Dry matter mass of neem leaves after cutting (regrowth), at different levels of bovine manure $\left(\hat{\mathrm{Y}}_{\mathrm{EB}}\right)$, common biofertilizer $\left(\hat{\mathrm{Y}}_{\mathrm{BC}}\right)$ and chemically enriched biofertilizer $\left(\hat{\mathrm{Y}}_{\mathrm{BE}}\right)$ treatment in saline-sodic soil.

As discussed for stem diameter (Figure 2), the chemically enriched biofertilizer, despite containing agricultural plaster rich in calcium, sulphur and other components with essential nutrients, such as iron and phosphorus (COPERSUCAR, 1988), did not surpass in absolute values the common biofertilizer in dry matter production of neem leaves (Figure 4).

The supremacy of bovine manure over common and enriched biofertilisers, as shown for stem and leaf dry matter was also found for shoot dry matter, being the sum of stem, leaves and branches (Figure 5). The increases were from 16.31 to $47.48 \mathrm{~g}$, from 13.61 to $19.23 \mathrm{~g}$ and from 12.96 to $21.63 \mathrm{~g}$, respectively between plants treated with bovine manure, common biofertilizer and enriched input with agricultural plaster, milk and molasses.

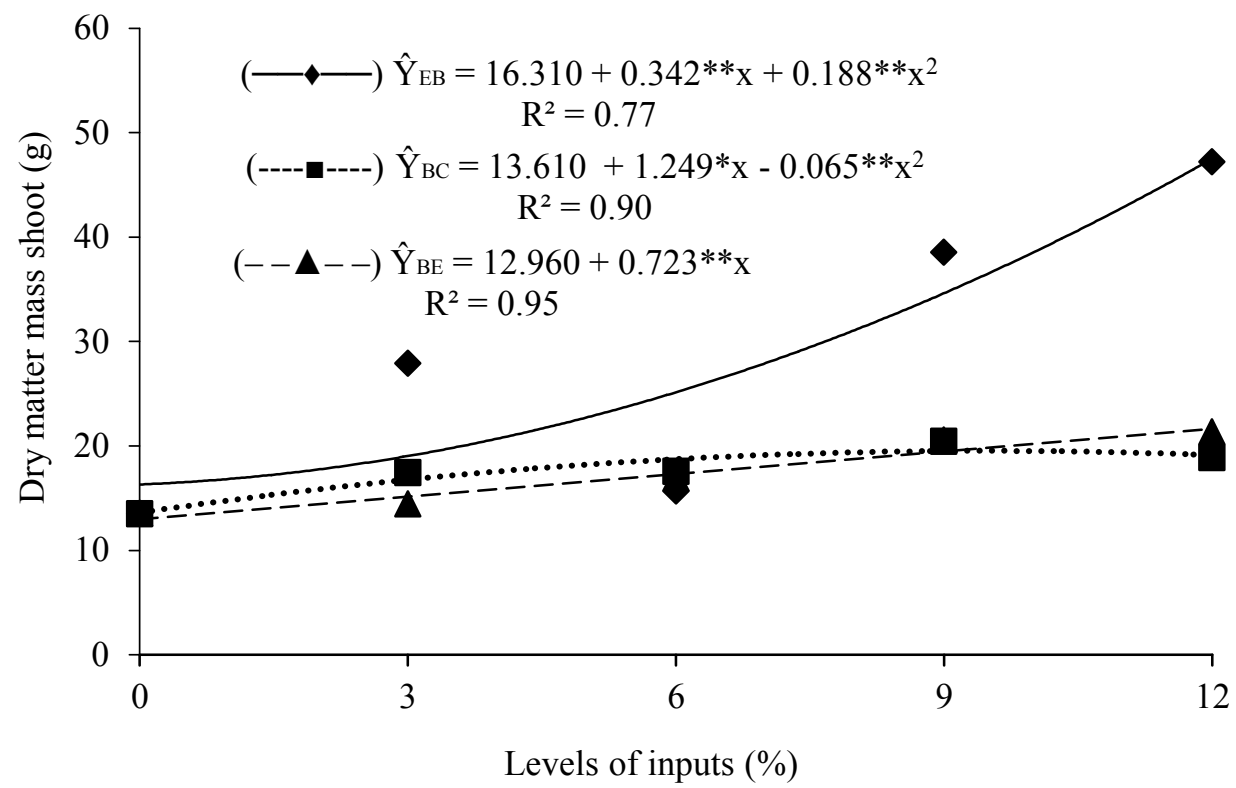

Figure 5. Dry matter of neem shoots (stem and leaves) after cutting (regrowth) at different levels of bovine manure $\left(\hat{\mathrm{Y}}_{\mathrm{EB}}\right)$, common biofertilizer $\left(\hat{\mathrm{Y}}_{\mathrm{BC}}\right)$ and chemically enriched biofertilizer $\left(\hat{\mathrm{Y}}_{\mathrm{BE}}\right)$ treatment in saline-sodic soil. 
The increases in plant mass (Figure 5) occurred due to the mineralisation of organic matter of animal or vegetable origin, which promotes the reduction of negative salinity effects (electrical conductivity of the saturation extract - ECse) and sodicity (percentage of exchangeable sodium PES) in saline (TEJADA et al., 2006), sodic (PAZHANIVELAN et al., 2006; CAMPOS et al., 2011) and saline-sodic soils (MIRANDA et al., 2011; REZAPOUR, 2014). The decomposition of organic matter is accompanied by $\mathrm{CO}_{2}$ release and organic acid production, contributing to the inhibition of the negative effects of salts on plants and the specific actions of sodium on the soil-plant system (FREIRE; FREIRE, 2007; MIRANDA et al., 2011). These beneficial functions of organic inputs resulted in greater plant growth, as verified by Pazhanivelan et al. (2006) and Freire et al. (2010), in soils degraded by salts.

In general, despite organic inputs raising the salinity and sodicity, as indicated in Table 3, they also exerted beneficial effects and stimulated both growth and yield of plant dry matter. Due to the simultaneous actions of salinity and sodicity, the presented data are similar to those observed by Diniz et al. (2013) and Mesquita et al. (2015), and Pazhanivelan et al. (2006) and Campos et al. (2011), respectively. The first two studies showed that although common biofertilizer inhibited the action of salinity in irrigation water during neem seedling formation, plant growth was compromised with increasing electrical conductivity of the irrigation water. The latter two studies showed that adding organic matter stimulated both neem and passion fruit plant growth in sodic soil.

\section{CONCLUSION}

Bovine manure is more efficient in promoting neem growth after cutting in saline-sodic soils, compared with common and chemically enriched biofertilisers.

Neem was confirmed to be moderately tolerant to soil salinity and sodicity during regrowth and initial growth.

Organic inputs increase both salinity and sodicity of soil, thus stimulating growth and regrowth of plants after cutting in saline-sodic soil.

\section{ACKNOWLEDGEMENTS}

The authors thank the National Institute of Science and Technology in Salinity - INCTSal and the National Council of Science and Technology $\mathrm{CNPq}$, for financial support and granting a scholarship to the first author.

\section{REFERENCES}

AYERS, R. S.; WESTCOT, D. W. A qualidade da água na agricultura. 2. ed. Campina Grande: UFPB, 1999. 153 p. (Irrigação e Drenagem, 29).

BENBOUALI, E, et al. Short-term effect of organic residue incorporation on soil aggregate stability along gradient in salinity in the lower Cheliff plain (Algeria). African Journal of Agricultural Research, Pretória, v. 18, n. 19, p. 2144-2152, 2013.

BRASIL. Regras para análise de sementes. 1. ed. Brasília, DF: Mapa/ACS, 2009. 395 p.

CAMPOS, V. B. et al. Esterco bovino líquido em luvissolo sódico: I. Resposta biométrica e produtiva do maracujazeiro amarelo. Idesia, Arica, v. 29, n. 2, p. 59-67, 2011.

COPERSUCAR. Fundamentos dos processos de fabricação de açúcar e álcool. 1 ed. Piracicaba: Copersucar, 1988. 12 p. (Série Industrial, 20).

DINIZ, B. L. T. et al. Crescimento inicial e consumo hídrico de nim submetido ao estresse salino e biofertilizante bovino. Revista Brasileira de Ciências Agrárias, Recife, v. 8, n. 3, p. 470-475, 2013.

DONAGEMA, G. K. et al. Manual de métodos de análise de solo. 2. ed. Rio de Janeiro, RJ: Embrapa Solos, $2011.230 \mathrm{p}$.

DUNJANA, N. et al. Effects of cattle manure on selected soil physical properties of smallholder farms on two soils of Murewa, Zimbabwe. Soil Use and Management, Oxford, v. 28, n. 2, p. 211-228, 2012.

FERREIRA, D. F. Sisvar: a computer statistical analysis system. Ciência e Agrotecnologia, Lavras, v. 35, n. 6, p. 1039-1042, 2011

FREIRE, A. L. O. et al. Crescimento e nutrição mineral do nim (Azadirachta indica a. juss.) e cinamomo (Melia azedarach Linn.) submetidos à salinidade. Ciência Florestal, Santa Maria, v. 20, n. 2, p. $207-215,2010$

FREIRE, M. B. G. S.; FREIRE, F. J. Fertilidade do solo e seu manejo em solos afetados por sais. In: NOVAIS, R. F. et al. (Eds.). Fertilidade do solo. Viçosa: SBCS, 2007, v. 1, cap. 16, p. 929-954.

GHRAB, M. et al. Water relations and yield of olive tree (cv. Chemlali) in response to partial root-zone drying (PRD) irrigation technique and salinity under arid climate. Agricultural Water Management, Amsterdam, v. 123, n. 1, p. 1-11, 2013. 
GURUMURTHY, B. R. et al. Influence of soil salinity on relative biomass and critical limits of growth in selected tree species. Karnataka Journal Agriculture Science, Dharwad, v. 20, n. 1, p. $133-134,2007$.

HOLANDA, A. C. et al. Desenvolvimento inicial de espécies arbóreas em ambientes degradados por sais. Revista de Biologia e Ciências da Terra, Campina Grande, v. 7, n. 1, p. 39-50, 2007.

ISLA, R.; GUILLÉN, M.; ARAGÜÉS, R. Response of five tree species to salinity and water logging: Shoot and root biomass and relationships with leaf and root ion concentrations. Agroforestry Systems, Dordrecht, v. 88, n. 3, p. 461-477, 2014.

LEITE, E. M. et al. Redução da sodicidade em solo irrigado com a utilização de ácido sulfúrico e gesso agrícola. Revista Caatinga, Mossoró, v. 23, n. 2, p. 110-116, 2010 .

MAHMOODABADI, $M$. et al. Reclamation of calcareous saline sodic soil with different amendments (I): Redistribution of soluble cations within the soil profile. Agricultural Water Management, Amsterdam, v. 120, n. 1, p. 30-38, 2013.

MARROCOS, S. T. P. et al. Composição química e microbiológica de biofertilizantes em diferentes tempos de decomposição. Revista Caatinga, Mossoró, v. 25, n. 4, p. 34-43, 2012.

MESQUITA, F. O. et al. Formação de mudas de nim com aplicação de biofertilizante bovino submetido à drenagem e estresse salino. Bioscience Journal, Uberlândia, v. 31, n. 1, p. 47-54, 2015.

MIRANDA, M. A. et al. Condicionadores químicos e orgânicos na recuperação de solo salino-sódico em casa de vegetação. Revista Brasileira de Engenharia Agrícola e Ambiental, Campina Grande, v. 15, n. 5, p. 484-490, 2011.

NASCIMENTO, I. R. et al. Determination of the mineral composition of fresh bovine milk from the milk-producing areas located in the State of Sergipe in Brazil and evaluation employing exploratory analysis. Microchemical Journal, New York, v. 96, n. 1, p. 37-41, 2010.

OMKAR, G. M. Neem, the wonder tree, under attack: A new major pest. Current Science, Bangalore, v. 102, n. 7, p. 960-970, 2012.

PAZHANIVELAN, S. et al. Influence of planting techniques and amendments on the performance of neem (Azadirachta indica) and changes in soil properties in rainfed alkali soil. Research Journal of
Agriculture and Biological Sciences, Jordan, v. 2, n. 6 , p. 443-446, 2006.

REZAPOUR, S. Effect of sulfur and composted manure on $\mathrm{SO}_{4}-\mathrm{S}, \mathrm{P}$ and micronutrient availability in a calcareous saline-sodic soil. Chemistry and Ecology, Ancona, v. 30, n. 2, p. 147-155, 2014.

RICHARDS, L. A. Diagnosis and improvement of saline and alkaline soils. Washington: United States Salinity Laboratory Staff, 1954. 160p. (Agriculture Handbook, 60).

RODRIGUES, R. M. Avaliação do nim (Azadirachta indica A. Juss.) como alternativa à recuperação de áreas degradadas por sais. 2011. 74 f. Dissertação (Mestrado em Agronomia) Universidade Federal da Paraíba, Areia, 2011.

ROY, S. J.; NEGRÃO, S. TESTER, M. Salt resistant crop plants. Current Opinion in Biotechnology, Cambridge, v. 26, n. 1, p. 115-124, 2014.

SANTOS, H. G. et al. Sistema brasileiro de classificação de solos. 3. ed. Brasília, DF: Embrapa Solos 2013. 353 p.

SILVA, A. F. et al. Preparo e uso de biofertilizantes líquidos. Petrolina: Embrapa Semi-Árido, 2007. 4 p. (Comunicado Técnico, 130).

SILVA, V. B. et al. Decomposição e liberação de N, $\mathrm{P}$ e K de esterco bovino e de cama de frango isolados ou misturados. Revista Brasileira de Ciência do Solo, Viçosa, v. 38, n. 4, p. 1537-1546, 2014.

TEJADA, M. et al. Use of organic amendment as a strategy for saline soil remediation: Influence on the physical, chemical and biological properties of soil. Soil Biology \& Biochemistry, Elmsford, v. 38, n. 6, p. 1413-1421, 2006. 